\title{
Soil fertility status and nutrient index for primary nutrients in Western Ghats and Coastal Karnataka under different agro-ecological systems
}

\section{SIDHARAM PATIL, K. S. ANIL KUMAR AND C. A. SRINIVASAMURTHY}

Received : 30.10.2017; Revised : 15.11.2017; Accepted : 24.11.2017

\author{
MEMBERS OF RESEARCH FORUM: \\ Corresponding author : \\ SIDHARAM PATIL, University of \\ Agricultural Sciences, BENGALURU \\ (KARNATAKA) INDIA \\ Email: patilsidhu01@gmail.com
}

Co-authors :

K.S. ANIL KUMAR, ICAR-National Bureau of Soil Survey and Land Use Planning, BENGALURU

(KARNATAKA) INDIA

\section{A. SRINIVASAMURTHY,}

University of Agricultural Sciences, BENGALURU (KARNATAKA) INDIA

\begin{abstract}
Summary
Study was undertaken in Western Ghats and Coastal area in Karnataka state, India with the aim of evaluating the fertility status of soils using nutrient index approach, mainly for primary nutrients. Based on fertility ratings, $\mathrm{pH}$ of soils was strongly acidic to moderately acidic. Electrical conductivity was normal $\left(<1.0 \mathrm{dS} \mathrm{m}^{-1}\right)$. Soil organic carbon was medium to high. Primary nutrient status i.e., N, P and $\mathrm{K}$ were low in $>60 \%$ samples. Whereas, $>80 \%$ of samples were low in exchangeable $\mathrm{Ca}, \mathrm{Mg}$ and available $\mathrm{S}$ content. Among the micronutrients $\mathrm{Cu}$ and $\mathrm{B}$ were found to be low in $>70 \%$ of samples, whereas $\mathrm{Fe}, \mathrm{Mn}$ and $\mathrm{Zn}$ were adequate in $>85 \%$ of samples. Nutrient index value for major nutrients (available $\mathrm{N}$, available $\mathrm{P}$ and available $\mathrm{K}$ ) was found to be low ( $<1.67$ range).
\end{abstract}

Key words : Fertility, Primary, Nutrient index, Micronutrients

How to cite this article : Patil, Sidharam, Kumar, K.S. Anil and Srinivasamurthy, C.A. (2017). Soil fertility status and nutrient index for primary nutrients in Western Ghats and Coastal Karnataka under different agro-ecological systems. Asian J. Soil Sci., 12 (2) : 314-319 : DOI : 10.15740/HAS/AJSS/12.2/ 314-319. 